\title{
THE GENETIC BASIS OF GENDER IN SILENE VULGARIS
}

\author{
A. HOROVITZ* AND R. DULBERGER ${ }^{\dagger}$ \\ * Department of Genetics, The Hebrew University, Jerusalem \\ t Department of Botany, The George S. Wise Faculty of Life Sciences, \\ Tel Aviv University, Israel
}

Received 26.xi.82

\section{SUMMARY}

\begin{abstract}
Inheritance of gender was studied in tetraploid Silene vulgaris in Israel. Three main phenotypes, hermaphrodite, $\mathrm{H}$, female, $\mathrm{F}$, and intermediate $\mathrm{HF}$, were recognized. With the support of data from crosses within and between the phenotypes it is postulated that basic gender is controlled at a single tetrasomic locus $A A / a a$. Quadruplex and triplex $A A A A$ and $A A A a$ individuals exhibit phenotype $\mathrm{H}$, simplex and nulliplex $a a a a$ and $A a a a$ individuals phenotype $\mathrm{F}$, and $A a A a$ individuals phenotype HF. Predominantly hermaphrodite or predominantly female subgroups of the HF phenotype are liable to be confused with true $\mathrm{H}$ or $\mathrm{F}$ types, so that misclassifications may blurr the underlying genetic pattern. In the HF phenotype, in which $A$ is assumed to be incompletely dominant over $a$, expression of male sterility is confined to single flowers or single anthers in a pattern with the appearance of randomness. The question is asked whether the mosaic pattern of sex expression in heterozygotes may reflect vegetative segregation of dissimilar cytoplasmic male sterility factors which are controlled by nuclear restorer genes.
\end{abstract}

\section{INTRODUCTION}

The Bladder campion Silene vulgaris (Moench) Garcke, Caryophyllaceae, is polymorphic in gender and of ten forms mixed populations which comprise hermaphrodite, male sterile, and gynomonoecious individuals. Sex inheritance in this species has been investigated in a number of studies over a long span of time (Correns, 1904, 1906; Marsden-Jones and Turrill, 1957); however, no clear pattern has emerged.

In the present work the genetic basis of sex polymorphism in S. vulgaris was examined in plants derived from wild populations in Israel. The local plant material is stoloniferous and shows a good morphological fit to subsp. macrocarpa Turrill (Turrill, 1956). Sex-linked polymorphism in floral and related traits has been investigated in a parallel study (Dulberger and Horovitz, in preparation). All samples examined in our area were found to be tetraploid, $2 n=48$. Tetraploidy in Silene vulgaris has also been reported from other parts of the Mediterranean region, namely from Portugal, Northern Italy, Southern France, Greece and some Aegean islands, as well as from the Canaries (reviewed by Melzheimer and Damboldt, 1973).

Instability in sex expression and gynomonoecy appear to be a special feature of $S$. vulgaris, and we present our data as a case study of hereditary patterns underlying gynomonoecy in a sexually polymorphic species.

\section{INHERITANCE OF MALE STERILITY}

A number of gender phenotypes were recognized in $S$. vulgaris: i. stable hermaphrodite plants in which all flowers are bisexual, ii. stable female 
plants in which all flowers are male sterile; iii. polygamous plants with bisexual, male sterile, and/or partially male sterile flowers. Following Marsden-Jones and Turrill (1957), we designated group i hermaphrodite

TABLE 1

Results of progeny tests

\begin{tabular}{|c|c|c|c|c|c|c|c|}
\hline $\begin{array}{l}\text { No. of } \\
\text { cross }\end{array}$ & $\begin{array}{c}\text { Acc. No. } \\
\text { of } \\
\text { family* }\end{array}$ & Parents** & $\begin{array}{c}\text { Proge } \\
\mathrm{H} \\
A A A A \\
\text { or } \\
A A A a\end{array}$ & $\begin{array}{c}\text { eny segre: } \\
\text { HF } \\
A a A a\end{array}$ & $\begin{array}{c}\text { Fation } \\
\text { Faaa } \\
\text { or } \\
\text { aaaa }\end{array}$ & $\begin{array}{l}\text { Expected } \\
\text { ratios of } \\
H: H F: F\end{array}$ & $\mathrm{P} \% * * *$ \\
\hline $\begin{array}{l}1 \\
2\end{array}$ & $\begin{array}{c}1 \\
\quad 610 \\
\text { Combined } \\
\text { Heterogenei }\end{array}$ & $\begin{array}{c}\mathrm{F} \times \mathrm{H} \\
\text { Aaaa } \times \text { AAAa } \\
\mathrm{P} 1 \times \mathrm{P} 3 \\
2-12 \times 1-51 \\
\text { ty } \chi^{2}(3 \text { d.f. })\end{array}$ & $\begin{array}{r}14 \\
7 \\
21\end{array}$ & $\begin{array}{l}31 \\
23 \\
54\end{array}$ & $\begin{array}{r}8 \\
9 \\
17\end{array}$ & $\begin{array}{r}\chi^{2} 3 \cdot 130 \\
1 \cdot 184\end{array}$ & $\begin{array}{l}10-25 \\
75-90\end{array}$ \\
\hline
\end{tabular}

$\mathrm{FH}$

\begin{tabular}{|c|c|c|c|c|c|c|c|}
\hline 3 & 2 & $\begin{array}{c}a a a a \times A A A a \\
\mathrm{P} 2 \times \mathrm{P} 3\end{array}$ & - & 16 & 22 & $\begin{array}{c}0: 1: 1 \\
\chi^{2} 0.658\end{array}$ & $25-50$ \\
\hline $\begin{array}{r}4 \\
5 \\
6 \\
7 \\
8 \\
9 \\
9 \\
10\end{array}$ & $\begin{array}{c}603 \\
606 \\
607 \\
612 \\
613 \\
7806 \\
7808 \\
\text { Combined } \\
\text { Heterogenei }\end{array}$ & $\begin{array}{c}\mathrm{F} \times \mathrm{HF} \\
\text { Aaaa } \times \text { AaAa } \\
2-5 \times 1-53 \\
2-12 \times 1-34 \\
2-12 \times 1-48 \\
2-5 \times 1-6 \\
2-6 \times 1-48 \\
613-11 \times 613-9 \\
603-29 \times 603-53 \\
\text { ity } \chi^{2} \text { (11 d.f.) }\end{array}$ & $\begin{array}{r}2 \\
1 \\
5 \\
1 \\
-1 \\
10\end{array}$ & $\begin{array}{r}30 \\
6 \\
20 \\
5 \\
3 \\
5 \\
5 \\
74\end{array}$ & $\begin{array}{r}34 \\
3 \\
26 \\
7 \\
\\
2 \\
6 \\
78\end{array}$ & $\begin{array}{r}x^{2} 1.318 \\
12 \cdot 031\end{array}$ & $\begin{array}{l}50-75 \\
25-50\end{array}$ \\
\hline $\begin{array}{l}11 \\
12 \\
13 \\
14 \\
15\end{array}$ & $\begin{array}{c}\quad 604 \\
605 \\
609 \\
611 \\
7807 \\
\text { Combined } \\
\text { Heterogenei }\end{array}$ & $\begin{array}{c}\mathrm{HF} \times \mathrm{HF} \\
\text { AaAa } \times A a A a \\
1-34 \text { selfed } \\
2-9 \text { selfed } \\
1-41 \times 1-53 \\
2-9 \times 1-53 \\
608-39 \text { selfed } \\
\text { ity } \chi^{2} \text { (3 d.f.) }\end{array}$ & $\begin{array}{l}2 \\
1 \\
3 \\
1 \\
2 \\
9\end{array}$ & $\begin{array}{r}3 \\
3 \\
8 \\
3 \\
2 \\
19\end{array}$ & $\begin{array}{r}1 \\
2 \\
2 \\
2 \\
3 \\
10\end{array}$ & $\begin{array}{r}\chi^{2} 0.105 \\
0.473\end{array}$ & $\begin{array}{l}90-95 \\
90-95\end{array}$ \\
\hline $\begin{array}{l}16 \\
17\end{array}$ & $\begin{array}{l}\quad 602 \\
\quad 608 \\
\text { Combined } \\
\text { Heterogenei }\end{array}$ & $\begin{array}{c}\mathrm{H} \times \mathrm{HF} \\
A A A a \times A a A a \\
1-51 \times 1-53 \\
1-51 \times 1-48 \\
\text { ity } \chi^{2}(3 \text { d.f. })\end{array}$ & $\begin{array}{l}11 \\
10 \\
21\end{array}$ & $\begin{array}{r}20 \\
4 \\
24\end{array}$ & $\begin{array}{l}4 \\
2 \\
6\end{array}$ & $\begin{array}{r}x^{2} 1.870 \\
5.576\end{array}$ & $\begin{array}{l}25-50 \\
10-25\end{array}$ \\
\hline
\end{tabular}

${ }^{*}$ Accession numbers 1 and 2 denote $F_{1}$ families; 3 -digit numbers beginning with $6-F_{2}$ families, and 4-digit numbers beginning with $7-\mathrm{F}_{3}$ families. number.

** Individual plants in a family are designated by plant numbers following the accession

${ }^{* * *}$ In all families of 10 or more, deviations from the expected are insignificant, $\chi^{2}$ test. To achieve minimal expected levels, families of less than 10 have been pooled in the heterogeneity tests. 
individuals as $\mathrm{H}$, group ii females as $\mathrm{F}$, and group iii plants with hermaphrodite plus female flowers as HF. Most of the F plants produce flowers with shrivelled anthers on short filaments. In a less common $F$ phenotype, minuscule sterile anthers are borne on filaments of normal length or the two flower types occur on the same plant, or the two kinds of aborted stamens in the same flower. The diverse types of stamen abortion are also exhibited by the HF group. The HF category could be further subdivided into three subphenotypes: $\mathrm{HF}_{\mathrm{i}}$ plants are unstable hermaphrodites in which the entire androecium or a single whorl of statemens or a single stamen in a flower are aborted in rare instances; $\mathrm{HF}_{\mathrm{ii}}$ plants are gynomonoecious and bear bisexual, partially male sterile, and fully male sterile flowers; $\mathrm{HF}_{\mathrm{iii}}$ plants are unstable females which produce viable stamens or stamen complements in rare instances.

To minimize misclassifications caused by instability of sex expression, determinations of gender were based on at least six examinations of a plant at different spaced out dates or on examinations of at least nine inflorescences (more than 200 flowers) in each case. Even group $\mathrm{HF}_{\mathrm{ii}}$ gynomonoecious individuals produced homogamous inflorescences on occasion, so that their true gender was not always revealed at a first scoring.

Progeny tests were performed to test the inheritance of gender (table 1). In view of the relatively small number of plants analysed, we present the manner in which the data were obtained in some detail. All progenies were derived from two crosses between plants from Mt Carmel populations. Two parent plants of phenotype $F\left(\mathrm{P}_{1}\right.$ and $\left.\mathrm{P}_{2}\right)$ which had been raised in the Botanical Garden of Tel Aviv University, were pollinated with flowers from a wild growing pollen donor $\left(\mathbf{P}_{3}\right) . \mathbf{P}_{3}$ was not available for further study, and its $\mathrm{H}$ rather than HF phenotype was determined by progeny analysis. The crosses yielded the $F_{1}$ families 1 and 2 (table 1 ). Plants assumed to be representatives of the different phenotypes were selected from the $F_{1}$ generation to produce $F_{2}$ families and, similarly, a small number of $F_{3}$ families were produced from crosses or selfings of $F_{2}$ plants, as shown in table 1 . The progenies were maintained in garden plantings at Tel Aviv University and flowered between March and June. The $F_{1}$ accessions were kept under observation during two to three growing seasons, and confirmation of phenotypes of plants selected for crosses continued in parallel with the analysis of their progenies. $F_{2}$ and $F_{3}$ accessions were examined in detail for only a single season, and only 77 per cent of the plants raised to flowering produced sufficient numbers of inflorescences for phenotype determination and inclusion in the counts shown in the table.

Since the material is tetraploid and the appearance of occasional quadrivalents on the meiotic plate suggests autotetraploidy, the hypothesis that the three phenotypes $\mathrm{H}, \mathrm{F}$, and $\mathrm{HF}$ are controlled at a single tetrasomic locus $A A / a a$ was tested. The data presented in the table are consistent with chromosome segregation (Burnham, 1962) of such a locus. Progeny segregations show a good fit to the expected when there is no crossing over between the tetrasomic locus and the centromere.

By this interpretation, both $A A A A$ and triplex $A A A a$ genotypes are of phenotype $\mathrm{H}$; in the first case only $A A$ gametes are produced and, in the second, equal proportions of $A A$ and $A a$. Phenotype $\mathrm{F}$ is exhibited by both aaaa plants which produce $a a$ gametes, and by simplex Aaaa 
plants which produce equal proportions of $A a$ and $a a$ gametes. $A a A a$ plants are of the phenotype $\mathrm{HF}$ and produce $A A, A a$, and $a a$ gametes in the proportion of $1: 4: 1$. No attempt was made to analyze genetic factors responsible for differences in stability of sex expression in the $\mathrm{HF}$ group, viz., categories $\mathrm{HF}_{\mathrm{i}}, \mathrm{HF}_{\mathrm{ii}}$, and $\mathrm{HF}_{\mathrm{iij}}$.

The four groups of crosses that could be analysed were $\mathrm{F} \times \mathrm{H} ; \mathrm{F} \times \mathrm{HF}$; $\mathrm{HF} \times \mathrm{HF}$; and $\mathrm{H} \times \mathrm{F}$ (table 1 ). The combination $\mathrm{H} \times \mathrm{H}$ was planned but not obtained because of misclassification of plant 1-53, which was assumed to have an $\mathrm{H}$ phenotype when introduced into the crosses; cross 16 , table 1 , should have yielded an $\mathrm{H} \times \mathrm{H}$ family. Both true $\mathrm{H}$ phenotypes used in the crosses, plants $\mathrm{P}_{3}$ and 1-51, were assumed to have a triplex $A A A a$ genotype. Of the $\mathrm{F}$ phenotype only plant $\mathrm{P}_{2}$ used in cross 3 had an assumed nulliplex aaaa genotype; all other $F$ parents shown in table 1, 2-5, 2-6, $2-12,603-29$, and 613-11 appeared to have a simplex Aaaa genotype. However, also without all possible combinations having been tested, we propose a tetrasomic mode of inheritance as a usable working hypothesis. Quadruplex and triplex hermaphrodite genotypes on the one hand, and simplex and nulliplex male sterile genotypes on the other, are indistinguishable phenotypically and can only be identified from their progenies.

\section{Discussion}

By our hypothesis, properly identified diploid $\mathrm{H}$ phenotypes should breed true when selfed or intercrossed, and $\mathrm{F} \times \mathrm{H}$ crosses should yield unstable HF plants. This hypothesis is not borne out by the wealth of segregation data on diploid $\boldsymbol{S}$. vulgaris presented by Marsden-Jones and Turrill in their monograph on the Bladder campions (1957). Even assuming that parent plants considered to be of phenotype $\mathrm{H}$ were misidentified and were in truth $\mathrm{HF}$ plants, the $\mathrm{H}: \mathrm{HF}: \mathrm{F}$ segregation ratios of their self progenies cannot be reconciled with a $1: 2: 1$ ratio. Perhaps progenies were misclassified because insufficient flowers were examined. The data of Correns $(1904,1906)$, which were presumably also obtained in diploids, show a somewhat better but still incomplete fit to our hypothesis. Correns himself (1906) remarks on plants included as hermaphrodites in progeny analyses on the basis of a first growing season, which produced male sterile flowers in a second season.

The model of gender inheritance presented here assumes autopolyploidy. Thus meiotic irregularities might be the cause of pollen abortion of the order of 30 per cent, noted by Dulberger and Horovitz (in preparation) in local $S$. vulgaris flowers with normally dehiscing anthers. Pollen abortion was also found in tetraploid $S$. vulgaris in Greece by Melzheimer and Damboldt (1973), though not in every individual. The sample of meiotic plates examined by us was too small to verify high incidence of meiotic irregularities which would cause pollen abortion. In fact, chromosome doubling may have been attended by bivalentization, as in the classical case of Lotus corniculatus (Dawson, 1941), in which the tetrasomic pattern of inheritance is the only indication of autopolyploidy.

If meiosis is more or less regular, pollen abortion in hermaphrodite flowers with normally dehiscing anthers is not necessarily a by-product of autopolyploidy. The question may then be asked whether the $a$ allele in the nucleus of PMCs has an adverse effect on the viability of the ensuing 
microspores. The segregation data shown for our material in table 1 make a gametophytic selection against $a a$ grains unlikely. There is no indication of distorted segregation ratios. However, equal abortion of $A a$ and $a a$ grains borne on heterozygous sporophytes is feasible. This would imply autonomy of cytoplasmic, non-nuclear, male sterility factors during the male gametophytic phase.

Continuous variation in the size of stainable and, at an overlapping lower range, nonstaining grains was noted in the present plant material by Dulberger and Horovitz (op. cit.). Similar observations in stainable grains were made by Melzheimer and Damboldt (1973) in Greek $S$. vulgaris and by Baker (1966) in $S$. maritima. In all three studies the plant material under investigation was polymorphic in gender. Male sterility has been reported in numerous species of the genus Silene (Friedrich, 1979) and it would be of interest to know whether variation in the size of pollen grains in this genus is characteristic of taxa with a propensity for male sterility. Here too, the possibility cannot be ruled out that grain size is affected by presence of alleles in the sporophytic genome, which code for male sterility, i.e., an $A A A a$ or $A A a a$ genome in Greek and Israeli tetraploids and an $A a$ genome in the presumably diploid $S$. maritima studied by Baker (op. cit.). Alternatively, variation in pollen grain size may be unrelated to gender genotype and should then also be exhibited by plants in which homozygosity for $A$ has been verified.

Our data can be explained by a simple model of wholly nuclear control, as shown. Instability in the gender of heterozygotes can perhaps be accounted for by the presence of only threshold amounts of male sterility suppressing DNA in their nuclei. Expression or suppression of male sterility could then depend on external or internal plant environment. Yet we ask whether there is also room for the suggestion that male sterility conferring factors may be present secondarily in cytoplasmic DNA. This suggestion draws support from the mosaic pattern of gender distribution in heterozygotes.

The apparently random restriction of male sterility expression in individuals carrying an $a$ allele to single flowers, single whorls, or single anthers of the androecium or, possibly, to single microspores in an anther, would be in keeping with patterns of vegetative segregation of cytoplasmic factors in an heteroplasmic organism (Birky, 1978). There is increasing evidence that male sterility is mediated by organelle DNA (Vedel et al., 1982) and in particular mitochondrial DNA, e.g. in maize (Kemble et al., 1980) and in tobacco (Belliard et al., 1979). If cytoplasmic factors confer male sterility in $S$. vulgaris, $\boldsymbol{A}$ alleles can be regarded as restorer genes. By our model, such alleles are universally present in two or more doses in all sporophytes which produce viable pollen grains.

It has to be borne in mind that the model is based on the genetic variation present in only three plants. It is in need of verification on a wider scale on different backgrounds of plant material. The observation of different HF phenotypes suggests that additional nuclear genes may affect the assumed heterozygotes. Nuclear modifying factors could mask and stretch incomplete dominance in different directions, and such a situation could partly account for the vagueness that has shrouded the inheritance of male sterility in Silene vulgaris (Correns, 1906, 1908, and references to these papers in the last seven decades). 
Acknowledgements. We thank R. Falk for helpful critical comments on the manuscript and are grateful for suggestions received from anonymous reviewers.

\section{REFERENCES}

BAKER. H. G. 1966. The evolution of floral heteromorphism and gynodioecism in Silene maritima. Heredity, 21, 689-692.

BELIARD, G., VEDEL, F. AND PELETIER, G. 1979. Mitochondrial recombination in cytoplasmic hybrids of Nicotiana tabacum by protoplast fusion. Nature, 281, 401-403.

BIRKY, C. W. 1978. Transmission genetics of mitochondria and chloroplasts Ann. Rev. Genet., $12,471-512$.

Burnham, C. A. 1962. Discussions in Cytogenetics. Burgess Pub. Comp., Minneapolis.

CORRENS, C. 1904. Experimentelle Untersuchungen über die Gynodiöcie. Ber. deutsch. Bot. Ges., 22, 506-517.

CORRENS, C. 1906. Die Vererbung der Geschlechtsformen bei den gynodiöecischen. Pflanzen, Ber. deutsch. Bot. Ges., 24, 459-474.

CORRENS, C. 1908. Die Rolle der männlichen Keimzellen bei der Geschlechtsbestimmung der gynodiöecischen Pflanzen. Ber. deutsch. Bot. Ges., 26A, 686-701.

DAwsON, C. R. R. 1941. Tetrasomic inheritance in Lotus corniculatus L. J. Genet., 42, 49-72.

DULBERGER, R. AND HOROVITZ, A. Gender polymorphism in Silene vulgaris. (In preparation.)

FRIEDRICH, H. C. 1979 Silene L. In Hegi, G. Illustrierte Flora von Mittel-Europa Vol. III 2, 2nd edit., ed. K. H. Rechinger, 1043-1153.

KEMBLE, R. G., GUNN, R. E. AND FLAVELL, R. B. 1980. Classification of normal and male sterile cytoplasm in maize. II. Electrophoretic analysis of DNA species in mitochondria. Genetics, 95, 451-458.

MARSDEN-JONES, E. M. AND TURRILL, W. B. 1957. The Bladder Campions. Ray Society, London.

MELZHEIMER, V. AND DAMBOLDT, J. 1973. Zur Morphologie und Cytologie tetraploider Sippen von Silene vulgaris (Caryophyllaceae). Willdenowia, 7, 83-100.

TURRILL, W. B. 1956. Silene vulgaris (Moench) Garcke macrocarpa Turrill. Hooker's Icon. Plant, 5 ser. 6, tab. 3551, 1-3.

VEDEL, F., MATHIEU, C., LEBACQ, P., AMBARD-BRETTEVILLE, F., REMY, R., PELLETIER, G., RENARD, M. AND ROUSELLE, P. 1982. Comparative macronuclear analysis of cytoplasms of normal and cytoplasmic male sterile Brassica napus. Theor. Appl. Genet., 62, 255-262. 